\author{
Marcin KLEINOWSKI (D) \\ Nicolaus Copernicus University in Toruń \\ kleinowski@umk.pl
}

\title{
POLAND'S ABILITY TO BUILD BLOCKING COALITIONS AFTER BREXIT ${ }^{1}$
}

ABSTRACT The article presents the results of research on the impact of the United Kingdom's withdrawal from the European Union on Poland's ability to build small, minimal blocking coalitions in the Council of the European Union. To this end, the theory of voting games was used, but departing from the assumption that the creation of each possible coalition of players is equally likely. It was also assumed that they do not necessarily make decisions independently of each other, and the analysis focuses on the ability to build minimally blocking coalitions. The obtained results indicate that after Brexit, for Poland to build a blocking coalition in opposition to the German-French tandem will be a very difficult task, and the loss of the United Kingdom as a potential coalition partner in the Council may be irreplaceable in some matters.

Key words: Brexit, blocking coalitions, Council of the European Union

\footnotetext{
The presented research was financed by the National Science Centre, as part of project No. UMO2016/23/D/HS5/00408 (SONATA 12) entitled The Impact of Brexit and Unconditional Introduction of the "Double Majority" Voting System on the Decision-Making Process in the Council of the European Union.
} 


\section{INTRODUCTION}

In light of previous research, there is no doubt that decisions in the Council of the European Union are worked out primarily through consensual negotiations, ${ }^{2}$ and Member States do not generally begin talks with a cold calculation of the possibility of building a blocking coalition. ${ }^{3}$ Carried out implicitly rather than explicitly, voting boils down to the formal adoption of earlier arrangements. The culture of consensus is an important part of the political culture in the Council ${ }^{4}$ and, after the entry into force of the provisions of the Treaty of Lisbon, changes taking part within it can be observed. Raising an objection by those members of the Council that are unable to build a blocking coalition is considered exaggerated action. An informal rule operates, according to which all member states should defend the adopted common position in Council negotiations with the European Parliament. ${ }^{5}$

The decisions taken in the Council are relatively rarely contested by member states, whether by abstaining from voting, or by raising objections. ${ }^{6}$ However, legislative projects in which the positions of member states are strongly polarized are also proceeded upon. Although such cases are infrequent, they concern issues defined as being of significance for a "vital national interest", or important to party rivalry in the domestic arena. At the same time, they arouse intense media interest and focus the electorate's attention.

2 F.M. Häge, "Coalition Building and Consensus in the Council of the European Union", British Journal of Political Science vol. 43, no. 3 (2013), pp. 481-504; D. Heisenberg, “The Institution of 'Consensus' in The European Union: Formal Versus Informal Decision-Making in The Council”, European Journal of Political Research, vol. 44, no. 1 (2005), pp. 65-90.

3 M. Kleinowski, Sita państw w Unii Europejskiej. Pozaformalne wyznaczniki sity państw Radzie UE i Radzie Europejskiej, Toruń 2014, pp. 139-185.

4 J. Lewis, "The Janus Face of Brussels. Socialization and Everyday Decision Making in the European Union”, in J.T. Checkel (ed.), International Institutions and Socialization in Europe, Cambridge 2007, pp. 137-170; F.M. Häge, “Coalition Building and Consensus...”, pp. 481-504; J. Clark, A. Jones, “'Telling Stories about Politics': Europeanization and the EU's Council Working Groups", Journal of Common Market Studies, vol. 49, no. 2 (2011), pp. 341-366; M. Kleinowski, Sita państw..., p. 159.

5 S. Novak, Qualified Majority Voting from the Single European Act to Present Day: An Unexpected Permanence, Studies and Research, 88, p. 19, at < http://institutdelors.eu/wp-content/uploads/2018/01/ etud88_en-qualifiedmajority-voting-novak.pdf $>$.

6 F. Hayes-Renshaw, W. van Aken, H. Wallace, "When and Why the EU Council of Ministers Votes Explicitly”, Journal of Common Market Studies, vol. 44, no. 1 (2006), pp. 161-194; M. Kleinowski, "Konsensualne negocjacje czy głosowanie - kontestowanie aktów prawnych w Radzie UE", Studia Europejskie, no. 4 (2012), pp. 27-50, at <https://www.ce.uw.edu.pl/pliki/pw/marcin_kleinowski. pdf $>$; S. Hagemann, J. De Clerck-Sachsse, "Old Rules, New Game Decision-Making in the Council of Ministers after the 2004 Enlargement”, Centre for European Policy Studies Special Report (2007), at <http://aei.pitt.edu/11754/1/1470.pdf>; M. Mattila, "Contested Decisions: Empirical Analysis of Voting in the European Union Council of Ministers", European Journal of Political Research, vol. 43, no. 1 (2004), pp. 29-50; idem, "Voting and Coalitions in the Council after the Enlargement", in D. Naurin, H. Wallace (eds.), Unveiling the Council of the European Union. Games Governments Play in Brussels, Basingstoke 2008, pp. 23-35. 
This may explain why, in the course of carrying out institutional reforms in the European Union (EU), member states evaluated the system of weighing votes in the Council from the perspective of winning possible allies and building coalitions on specific issues, which could be the subject of decision-making. ${ }^{7}$ T. Sozański points out that while negotiating the provisions of the Treaty establishing a Constitution for Europe, member states were not so much interested in the value of mathematical indices of voting power as in the ability to build blocking coalitions consisting of a relatively small number of members. ${ }^{8}$ In view of the activity of facilitators in the decision-making process in the EU, such as the European Commission, the rotating presidency, and the President of the European Council, it is very difficult to build a blocking coalition consisting of a large number of states. Research presented by Thomson indicates that even in the case of legislative proposals that are very controversial in the Council, one can rarely count on the establishment of a blocking coalition of 10-12 countries.

Decisions in the EU are arrived at primarily through inter-institutional negotiations conducted in trilogues. ${ }^{10}$ However, the Council begins negotiations in a trilogue if there is a majority in the institution sufficient to adopt a common position. ${ }^{11}$ This suggests that the creation of a blocking coalition in the Council may affect not only the position of this institution in the legislative process, but also the outcome of the decision-making process.

Based on the analysis of all legislative projects on environmental policy proceeded upon in the Council between the first round of Eastern enlargement and the entry into force of the Treaty of Lisbon, A. Warntjen shows the existence of a positive correlation between the probability of success of a member state's requests and the number of votes backing a proposal. ${ }^{12}$ Requests for derogations, extensions, or lower standards more than twice as often ended in at least partial success, if they were filed by member states

A. Moberg, Is the Double Majority Really Double? The Second Round in the Debate of the Voting Rules in the EU Constitutional Treaty, Real Instituto Elcano Working Paper, no. 290, Madrid 2007, pp. 64-89.

8 T. Sozański, “The Conception of Blocking Power as a Key to the Understanding of the History of Designing Voting Systems for the EU Council", Decyzje, no. 22 (2014), p. 24.

9 Thomson's analysis includes 125 controversial legislative proposals, proceeded upon in the years 1996 2009. R. Thomson, Resolving Controversy in the European Union. Legislative Decision-Making before and after Enlargement, Cambridge 2011.

10 G.J. Brandsma, "Co-Decision after Lisbon: The politics of Informal Trilogues in European Union Lawmaking”, European Union Politics, vol. 16, no. 2 (2015), pp. 300-319; E. Bressanelli, Ch. Koop, Ch. Reh, "The Impact of Informalisation: Early Agreements and Voting Cohesion in the European Parliament”, European Union Politics, vol. 17, no. 1 (2016), pp. 91-113; H. Farrell, A. Héritier, The Invisible Transformation of Codecision: Problems of Democratic Legitimacy, SIEPS Report No. 7, Stockholm 2003, at <http://www.sieps.se/en/publications/2003/the-invisible-transformation-of-codecision-problems-of-democratic-legitimacy-20037/Sieps_2003_7.pdf?>.

11 Ch. Roederer-Rynning, J. Greenwood, “The Culture of Trilogues”, Journal of European Public Policy, vol. 22, no. 8 (2015), pp. 1148-1165.

12 A. Warntjen, "Do Votes Matter? Voting Weights and the Success Probability of Member State Requests in the Council of the European Union", Journal of European Integration, vol. 39, no. 6 (2017), pp. 673-687. 
that were able to form a blocking coalition in the Council. At the same time, obtaining partial concessions was definitely more likely than achieving full success. ${ }^{13}$ The results of Warntjen's research indicate that for member states a blocking coalition is a tool for forcing further discussion in the Council and strengthening their own position in negotiations conducted in order to reach a compromise.

One of the most important arguments for introducing the system of the so-called double majority of weighing votes in the Council and, thus, the abandonment of the Nice system, was the relative ease of adapting the new way of weighing votes in the event of accession of other states to the EU. However, when designing the double majority system, it was not anticipated that one of the largest member states would leave the EU. With a population of over 65.8 million people (12.85\% of the total EU population), the United Kingdom ranks, in this respect, third among the $28 \mathrm{EU}$ countries. Consequently, Brexit may be presumed to change the ability of member states to form winning and blocking coalitions in the Council. Thus, a question arises as to how the UK's withdrawal from the EU will affect Poland's ability to build blocking coalitions in this institution.

\section{NOTATION, DEFINITIONS AND METHODS}

Solving the posed research problem requires finding answers to at least two research questions:

1. How will Poland's ability to build minimal blocking coalitions in the Council, compared to that of Germany, France, Italy and Spain, change as a result of Brexit?

2. What will be Poland's ability to create minimal blocking coalitions in the Council, in opposition to the German-French tandem, after the UK's withdrawal from the EU?

In order to obtain answers to the posed research questions, the theory of cooperative games was applied and, in particular, the theory of proper simple games, also called voting games, was applied. ${ }^{14}$ Simple games are sometimes defined as ${ }^{15}$ a conflict in which the only objective is winning and the only rule is an algorithm to decide which coalitions of players are winning. ${ }^{16}$ It should be emphasized that the theory of cooperative games

13 In cases when the requests were put forward by member states that did not form a blocking coalition in the Council, $37 \%$ of such proposals resulted in at least partial success. In turn, $76 \%$ of requests put forward by a blocking minority were successful. Ibid., pp. 680-683.

14 G. Owen, Game Theory, 3rd ed., London 1995, p. 218.

15 The definition quoted above is often attributed to Von Neumann and Morgenstern, and their fundamental work Theory of Games and Economic Behavior is indicated as its source. In their monograph, however, this definition was not directly written in this form.

16 See: J.M. Bilbao et al., "Voting Power in the European Union Enlargement", European Journal of Operational Research, vol. 143, no. 1 (2002), p. 181; A. Belke, B. Styczynska, The Allocation of Power in the Enlarged ECB Governing Council: An Assessment of the ECB Rotation Model, Brussels 2004, p. 4. 
does not deal with such problems as the way in which players make their own choices within a coalition, or the way a coalition is formed, and thus the players' reaching an agreement to undertake joint action. Voting games are often used to model voting in decision-making bodies and to measure players' voting power.

For a simple game in which $n$ (voting) players take part, $N=\left\{i_{1}, i_{2}, \ldots, i_{n}\right\}$ is a nonempty, finite set of $S$ players, which is a subset of the set $N$. Each subset $S \subseteq N$ is referred to as a coalition, including also the empty set $\emptyset$, which is a coalition that contains no players. Like in Felsenthal and Machover, the term "coalition" is understood as any possible set of players. ${ }^{17}$ The number of players in a finite set, e.g. $S$ is marked as . Simple games in which are called n-person simple games. In simple games, for each set $S$ the characteristic function takes only one of two values. W stands for the set of all winning coalitions. The set $S$ is the winning coalition $S \in \mathrm{W}$ when and only when. If then and only then $S$ is not the winning coalition $S \notin \mathrm{W}$. A winning coalition is a set of players which, as part of the game, is sufficient to adopt and impose a decision on all players.

The simple game $\mathrm{G}$ is such a pair $(N, \mathrm{~W})$ that $^{18}$ :

- $\emptyset \notin \mathrm{W}$, an empty set, in which there are no players, cannot be a winning coalition;

- $\mathrm{N} \in \mathrm{W}$, a set of all players, is a winning coalition;

- If $S \in \mathrm{W}$ and $S \subseteq T$, then $T \in \mathrm{W}$ - if the set $S$ is a winning coalition and the set $T$ contains all players from the sets $S$, then the set $T$ is also a winning coalition.

Player $i$ is a swing member of the coalition $S$, if $S \in \mathrm{W}$ and $S \backslash\{i\}=0$, and thus when after player $i$ leaves coalition $S$, it ceases to be a winning coalition, and player $i$ has the so-called negative swing, or the ability to transform the winning coalition $S \in \mathrm{W}$ into the non-winning coalition $S \backslash\{i\} \notin \mathrm{W}$.

The set MW consists of all the subsets $N$ being minimal winning coalitions. Von Neuman and Morgenstern proposed the concept of a minimal winning coalition, defining it as a set of these elements of $S \in \mathrm{W}$ of which no proper subset ${ }^{19}$ belongs to $\mathrm{W}^{20}$ Deegan and Packel define a minimal winning coalition in the following way:

$\mathrm{MW}=\{S \in \mathrm{W} \mid \forall$ of the non-empty $T \subseteq S \wedge S \backslash T \notin \mathrm{W}\} .^{21}$

The above definitions show that for every coalition $S \in \mathrm{W}$, the set $S$ is called a minimal winning coalition, if and only if $S \backslash i \notin \mathrm{W}$ for each $i \in S$. Hence, in a minimal winning coalition, each player is a swing member of the coalition.

The $S$ set for which can be a losing or blocking coalition. B is a set of blocking coalitions for $N$. The set $S \in \mathrm{B}$, if $S \notin \mathrm{W}$ and $N \backslash S \notin \mathrm{W}$. The set $S$ is the minimal blocking coalition $S \in \mathrm{MB}$, if no proper subset of $S$ belongs to $\mathrm{B}$, hence:

17 D.S. Felsenthal, M. Machover, The Measurement of Voting Power. Theory and Practice, Problems and Paradoxes, Cheltenham 1998, pp.16-17.

18 J.C. Harsanyi, R. Selten, A General Theory of Equilibrium Selection in Games, Cambridge 1988, pp. 3-4.

19 Set $A$ is a proper subset of the superset $B$, if it consists only of elements included in set $B$ and, at the same time, does not contain at least one element from set $A$.

20 J. Von Neumann, O. Morgenstern, Theory of Games and Economic Behavior, Princeton 1944, p. 430.

21 J. Deegan, E.W. Packel, “A New Index of Power for Simple n-Person Games”, International Journal of Game Theory, vol. 7, no. 2 (1979), p. 114. 


\section{$\mathrm{MB}=\{S \in \mathrm{B} \mid \forall$ of the non-empty $T \subseteq S \wedge S \backslash T \notin B\}$.}

$\mathrm{L}$ is a family of subsets of the set $N$ called losing coalitions. The set $S$ is a losing coalition, if $N \backslash S \in \mathrm{W}$. Each proper subset of the set $S \in \mathrm{L}$ is a losing coalition.

Weighted voting games are a subclass of voting games. We define the decision-making threshold $q$ as the minimum, required number of votes that a coalition of players has to gather in order for the initiative proceeded upon to be accepted. By $w_{i}$ we mean the weight of player $i$ 's vote. The game $\left(N, w_{i \in N}, q\right)$ is called a weighted voting game, if $\Sigma_{i \in N} w_{i} \geq q$ and $i \in N w_{i}>0$, and the characteristic function takes the values:

$$
v(S)=\left\{\begin{array}{l}
1 \text { when } \sum_{i \in S} w_{i} \geq q \\
0 \text { when } \sum_{i \in S} w_{i}<q
\end{array}\right.
$$

The coefficient of blocking power was also used in the work ${ }^{22}$ to determine the participation of a given country (player) in possible minimal blocking coalitions with a certain number of members. It is defined as the ratio between the number of minimal blocking coalitions of $k$ players containing player $i$ and the number of all minimal blocking coalitions consisting of $k$ players. For a priori voting, this coefficient determines the probability that a given player will be a member of a minimal blocking coalition consisting of $k$ players. For example, if the coefficient of blocking power takes, in the case of player $i$, the value, it means that this player is a member of $75 \%$ of the minimal blocking coalitions possible to be created by $k$ players. At the same time, if player $i$ chooses to support a proposed legislative initiative, then the number of minimal blocking coalitions consisting of $k$ players will decrease by $75 \%$.

The presented research uses an original variant of voting games, which is distinguished by two characteristic features. First of all, the analysis is focused on the players' ability to build minimal blocking coalitions, and thus on the structure of blocking for voting games. This makes it possible to determine how a change in the vote weighing system in the Council affects the relative ability of individual states to create such coalitions, taking into account the decision-making threshold and the distribution of voting weights. From the perspective of individual players, it makes it possible to identify key partners needed to set up blocking coalitions. As a consequence, it may be an introduction to a qualitative analysis consisting in the assessment of the feasibility of establishing certain coalitions in the Council, by comparing the position taken by a given government in matters relevant to it with the preferences of the key partners needed to set up a blocking or winning coalition. Secondly, there is a departure from the assumption that the formation of each coalition of players is equally likely and that they independently decide on how to vote. As a consequence, to some extent, this makes it possible to take into account in the analysis the role that the agenda-setters (and, in the subject of the analysis, the European Commission in particular) play in the decision-making process. It also makes it possible to perform the analysis assuming that within the voting body there are groups of players with different preferences as regards a given issue. In the presented studies, an assumption was made that at least $55 \%$ of the Council's

22 T. Sozański, “The Conception of Blocking Power..., p. 14. 
members, including the majority of EU countries with a population of over 30 million, would be ready to support the European Commission's proposals.

Even in the case of draft legislation that raises great controversy in the EU, the chances of creating a blocking coalition consisting of 13 countries in the Council are very small. This is indicated by Thomson's research on legislative initiatives, in which strong divisions inside the Council were revealed, ${ }^{23}$ as well as the experience from proceeding upon Directive 2018/957 concerning the posting of workers in the framework of the provision of services, and the legislative package on EU-ETS reform. ${ }^{24}$

Cases in which member states are unable to adopt a common position in the Council are extremely rare. Of the $72 \mathrm{draft}$ legal acts proceeded upon under the co-decision/ ordinary legislative procedure, which were withdrawn by the European Commission between July 1, 2009 and December 31, 2018, ${ }^{25}$ only in the case of 10 was it impossible to reach political agreement or adopt a common position in the Council, including one case in which the Council considered the initiative as a violation of its exclusive competence.

In order to calculate the number of minimal blocking and minimal winning coalitions possible to be created, the POWERGEN 5.0 program was used as the research tool for the selected voting games. It contains a feature that makes it possible to prepare detailed coalition statistics for individual players. It also makes it possible to specify the minimum number of players necessary to create a blocking minority. None of the commonly available programs has such a function, and it is important in the analysis of the vote weighing system in the Council when adopting decisions by a qualified majority. After Brexit, in the so-called double majority system, a blocking coalition will consist of at least four members of the Council. ${ }^{26}$ In addition, the POWERGEN 5.0 program makes it possible to limit the analysis to only part of all possible combinations of players (coalitions), and thus to depart from the assumption that the creation of any coalition is equally likely.

It should be borne in mind that for the purpose of qualified majority voting in the Council, the EU population number is construed de facto as the number of residents. ${ }^{27}$

\section{R. Thomson, Resolving Controversy...}

24 In the case of Directive 2018/957 concerning the posting of workers in the framework of the provision of services, 11 countries were ready to raise their objections. On the other hand, in the case of the EUETS reform, at the session of the Environment Council on 28 February 2017, 11 and 9 member states, respectively, were ready to vote against the adoption of the first and the second presidency proposals to modify the general approach. In the final vote in the Council, not all of the above-mentioned countries decided to express their position by raising objections, or by abstaining from voting.

25 The oldest of the indicated 72 legislative initiatives was officially presented by the European Commission in December 2005.

26 Consolidated version of the Treaty on European Union, Art. 16(4), Official Journal of the European Union, C 202, 7 June 2016.

27 Regulation (EU) No 1260/2013 of the European Parliament and of the Council of 20 November 2013 on European demographic statistics Art. 5, Official Journal of the European Union, L 330, 10 December 2013. 
Each year, it is provided by Eurostat for all member states. ${ }^{28}$ The presented studies used the number of residents of individual EU states as at January $1,2017 . .^{29}$

The study uses the term "large member states", which means the six member states with the largest populations in the current 28-country European Union - and after the potential exit of the United Kingdom from the EU, the five states of Germany, France, Italy, Spain and Poland.

\section{THE IMPACT OF BREXIT ON THE ABILITY TO BUILD BLOCKING COALITIONS BY THE FIVE MEMBER STATES WITH THE LARGEST POPULATIONS}

After the UK's withdrawal from the EU, it will still be difficult to build a blocking coalition in which only one EU country with a population of more than 35 million participates. Table 1 presents the minimum number of countries needed in such a situation to form a blocking coalition in the Council in the case of selected member states and the Visegrad Group, both before and after Brexit.

Table 1. The minimum size of a blocking coalition in the Council, in which only one large member state participates - before and after the UK's withdrawal from the EU

\begin{tabular}{|c|c|c|}
\hline $\begin{array}{c}\text { Member states } \\
\text { participating in the blocking coalition }\end{array}$ & EU-28 & EU-27 after Brexit \\
\hline Germany & $1+8$ & $1+6$ \\
\hline France & $1+10$ & $1+7$ \\
\hline United Kingdom & $1+10$ & - \\
\hline Italy & $1+11$ & $1+8$ \\
\hline Spain & $1+12$ & $1+10$ \\
\hline Poland & $1+12$ & $1+11$ \\
\hline Visegrad Group & $4+9$ & $4+8$ \\
\hline
\end{tabular}

Source: Own calculations.

After the UK's withdrawal from the EU, the creation of a blocking coalition in the Council around one large state will become, hypothetically, slightly easier. In practice, however, both Poland and the Visegrad Group (V4) have only a theoretical possibility to build a blocking coalition consisting of 12 members of the Council, without the participation of another large state. It is very unlikely for Poland or for the V4 to succeed

28 Data on the number of residents of EU countries as on 1 January of a given calendar year are usually officially available around October.

29 Eurostat, Usually resident population on 1 January (last update on October 2, 2017), at <http://appsso. eurostat.ec.europa.eu/nui/show.do?dataset=demo_urespop\&lang=en>. 
in winning all member states with a population between 10 and 20 million for a blocking coalition. Consequently, this means that in the case mentioned above, the blocking coalition would have to number more than $13 \mathrm{EU}$ countries. However, such wide divisions almost never occur within the Council, and it has been a very rare case when 10-12 member states have approached a legislative initiative in the Council in a negative way. It should be borne in mind that, both before and after Brexit, a group of any $13 \mathrm{EU}$ countries can build a blocking coalition based on the criterion of the majority of states. Consequently, even after the UK's withdrawal from the EU, it is unlikely that a blocking coalition in the Council will be created by Poland without the support of another large member state, and that coordinating and presenting a common position within the Visegrad Group will not change the position of Poland in this case.

Table 2. The actual threshold of the number of states for QMV adopted decisions in the Council, on the initiative of the European Commission, in the case of opposition of selected states

\begin{tabular}{|c|c|c|c|c|c|c|}
\hline \multirow[b]{2}{*}{$\begin{array}{l}\text { States opposing the } \\
\text { initiative }\end{array}$} & \multicolumn{3}{|c|}{ EU 28} & \multicolumn{3}{|c|}{ EU 27 after Brexit } \\
\hline & 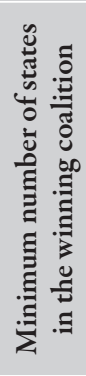 & 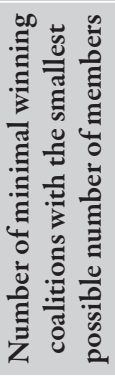 & 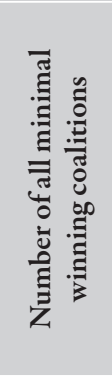 & 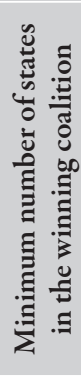 & 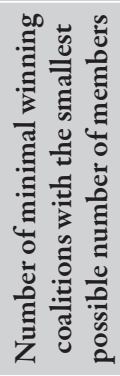 & 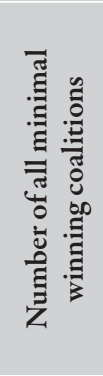 \\
\hline Germany, France & 16 & 75 & 4023 & 20 & 7 & 44 \\
\hline Germany, Italy & 16 & 1012 & 8345 & 18 & 5 & 193 \\
\hline Germany, Spain & 16 & 43849 & 60231 & 15 & 15 & 2805 \\
\hline Germany, Poland & 16 & 141771 & 157997 & 15 & 1086 & 8549 \\
\hline France, Italy & 16 & 49417 & 66231 & 15 & 22 & 3117 \\
\hline France, Spain & 16 & 264579 & 280084 & 15 & 8842 & 21116 \\
\hline France, Poland & 16 & 433716 & 443467 & 15 & 51154 & 67610 \\
\hline Italy, Poland & 16 & 383759 & 397416 & 15 & 31728 & 47248 \\
\hline Italy, Spain & 16 & 530437 & 539429 & 15 & 115196 & 131823 \\
\hline Spain, Poland & 16 & 640345 & 651819 & 15 & 384921 & 393463 \\
\hline Germany, V4 & 16 & 6974 & 7656 & 15 & 1 & 68 \\
\hline France, V4 & 16 & 29362 & 29767 & 15 & 1620 & 2186 \\
\hline Italy, V4 & 16 & 37912 & 38177 & 15 & 5238 & 5919 \\
\hline Spain, V4 & 16 & 48981 & 49054 & 15 & 25229 & 25741 \\
\hline
\end{tabular}

Source: Own calculations. 
Table 2 indicates that after Brexit it will become more difficult to adopt a decision in the Council against the position of two of the five Member States with the largest populations in the EU..$^{30}$

Comparing the left and right sides of Table 2, it should be noted that it will generally be more difficult to build a winning coalition facing the objection of two large member states, in particular Germany, France or Italy. Adopting a decision in the Council against the position of the German-French tandem will require the creation of a winning coalition consisting of at least 20 states. At the same time, only 44 such coalitions are possible to be set up. In the case of raising objections by Germany and Italy, the real decision-making threshold in the Council will have increased to at least 18 countries, with 193 minimal blocking coalitions possible to be built. This means that if these countries coordinate their positions presented in the Council, the European Commission will have to take due account of their interests at the stage of preparing the initiative. As a consequence, the position of the five largest member states will determine the scope of a possible compromise in the Council even more than before, with the particularly large influence of Germany and France.

After Brexit, in the situation of contesting decisions in the Council by Poland together with Germany or France, the creation of a winning coalition will be much easier than if two of the three EU countries with the largest populations raise their objections. This results from the Polish population being much smaller than that of Germany, France or Italy. In comparison to Spain as well, the difference in this regard is clear.

After the UK's withdrawal from the European Union, it will be much more difficult to build a winning coalition in the Council in the face of contesting the initiative by the Visegrad Group together with one large member state, in particular by presenting a common position with the German government. In the latter case, although it is possible to create a minimally winning coalition of 15 countries, only one such coalition actually exists. In the case of building a blocking coalition by Poland and Germany together, it would be necessary to recruit an additional 4-5 member states to create it. Therefore, in this situation, the presentation of a common position by the Visegrad Group raises the attractiveness of the states forming it as potential coalition partners. In economic and financial matters, the position of the Visegrad Group may be closer to the position taken by the German government than to the position of Spain. Should the position of Germany and the Visegrad Group states be supported by at least one member state of the group of Romania, the Netherlands, Belgium, Portugal, and Greece, then a blocking coalition would be formed in the Council. For Germany, after Brexit, cooperation with

30 It is very unlikely that three large member states would be forced to build a blocking coalition in the Council. In such a case, its creation would be almost certain. One cannot ignore the significant political power of such a group of states in the Council, which cannot be reduced only to the weight of their vote, either. Since the entry into force of the provisions of the Treaty of Lisbon, regarding the change of the Nice system of weighing votes in the Council to the so-called double majority system, there has been no case of a legislative initiative in which three large Member States would be forced to form a blocking coalition. Being aware of the difficulties this would mean for a planned initiative, the European Commission would rather take into account the interests of the largest member states in its proposal, or would give up putting forward the initiative, at least at a given time. 
the Visegrad Group to strengthen its negotiating position in the Council by creating a blocking coalition may become a viable alternative to its cooperation with Italy.

After the UK's withdrawal from the EU, in a situation in which the five biggest EU member states would be seeking to build a blocking coalition and three states are supporting the presented initiative, the Netherlands and Romania, the position of which would have a significant impact on the chances of creating a blocking coalition, could proverbially tip the balance.

In the case of coordinating the position in the Council by Germany and France, it is unlikely that these states should have to form a blocking coalition, as both their voting weight in the institution in question (cf. Table 2) and their political power are very strong. In such situations, Paris and Berlin usually form the backbone of a winning coalition in the Council. The cooperation of Germany and France in the EU forum has a significant impact on Poland's ability to build small, minimal blocking coalitions in the discussed institution. It should be anticipated that after Brexit Poland will usually be in opposition to Germany and France when building a blocking coalition in the Council. Consequently, without the support of Italy or Spain, the chances of blocking a decision by the government in Warsaw will be close to zero. Without the support of another large EU state, the creation of a blocking coalition by Poland requires the support of at least 11 Council members, and the possibility of building such a broad coalition is extremely small. Therefore, an important question arises here: to what extent can we count on the occurrence of a convergence of interests between Poland and Italy, or Poland and Spain?

Table 3 presents the blocking structure for the voting game in the Council with the following assumptions:

- qualified majority voting is applied ("double majority voting");

- the legislative initiative enjoys the support of at least $55 \%$ of EU states;

- the initiative is not supported by at most two member states with a population of over 35 million.

Although as a result of Brexit the number of all possible coalitions in the Council will be halved, the number of minimal blocking coalitions likely to be set up by 4-6 EU states will increase. This indicates that after the UK's withdrawal from the EU, it will become easier for large member states to build a blocking coalition consisting of 4-6 members, because it will be easier for especially the three states with the largest populations to find coalition members with a sufficiently large number of citizens. It will be difficult to push through the Council solutions that run counter to the position of two of the three largest states.

The number of blocking coalitions in the Council possible to be created by 7 or 8 countries will have decreased, which means that for member states with a population of less than 35 million people, it will be more difficult to create small blocking coalitions. Germany will gain a huge advantage in building the smallest minimal blocking coalitions. After Brexit, the five EU states with the largest populations will gain a greater capacity to build small, minimal blocking coalitions, although Poland will benefit from this change relatively less compared to the other members of this group. 
Table 3. Small, minimal blocking coalitions possible to be set up in the Council, assuming that at least $55 \%$ of member states and at least three large EU countries

support the initiative of the European Commission

\begin{tabular}{|c|c|c|c|c|c|c|c|c|c|c|}
\hline \multirow{3}{*}{ Member state } & \multicolumn{5}{|c|}{ EU 28} & \multicolumn{5}{|c|}{ EU 27 after Brexit } \\
\hline & \multicolumn{5}{|c|}{ The number of coalition members } & \multicolumn{5}{|c|}{ The number of coalition members } \\
\hline & 4 & 5 & 6 & 7 & 8 & 4 & 5 & 6 & 7 & 8 \\
\hline Germany & 7 & 382 & 1703 & 4838 & 9864 & 320 & 275 & 1260 & 2519 & 4504 \\
\hline France & 5 & 158 & 729 & 3106 & 8081 & 199 & 164 & 1059 & 3146 & 7046 \\
\hline United Kingdom & 1 & 177 & 763 & 3039 & 7963 & - & - & - & - & - \\
\hline Italy & 1 & 59 & 616 & 2894 & 8008 & 127 & 218 & 876 & 2323 & 6272 \\
\hline Spain & 0 & 0 & 82 & 940 & 4204 & 13 & 125 & 1147 & 3260 & 7438 \\
\hline Poland & 0 & 0 & 1 & 287 & 1814 & 1 & 54 & 586 & 2499 & 7314 \\
\hline Romania & 7 & 187 & 596 & 2697 & 7196 & 59 & 90 & 690 & 2052 & 5813 \\
\hline Netherlands & 3 & 166 & 549 & 2370 & 7332 & 52 & 135 & 580 & 1985 & 5567 \\
\hline Belgium & 1 & 92 & 515 & 2275 & 6571 & 43 & 66 & 679 & 1905 & 5386 \\
\hline Greece & 1 & 82 & 505 & 2338 & 6464 & 42 & 60 & 617 & 1984 & 5629 \\
\hline Czech Republic & 1 & 76 & 510 & 2323 & 6447 & 39 & 82 & 604 & 1911 & 5543 \\
\hline Portugal & 1 & 74 & 515 & 2289 & 6424 & 39 & 76 & 616 & 1954 & 5566 \\
\hline Sweden & 0 & 87 & 514 & 2225 & 6431 & 39 & 72 & 599 & 1987 & 5495 \\
\hline Hungary & 0 & 85 & 489 & 2219 & 6390 & 38 & 80 & 575 & 2001 & 5601 \\
\hline Austria & 0 & 65 & 509 & 2327 & 6321 & 37 & 69 & 469 & 2099 & 5477 \\
\hline Bulgaria & 0 & 42 & 498 & 1934 & 6516 & 32 & 83 & 499 & 1897 & 5238 \\
\hline Denmark & 0 & 34 & 408 & 1842 & 6297 & 28 & 52 & 572 & 1785 & 5291 \\
\hline Finland & 0 & 33 & 389 & 1846 & 6154 & 28 & 45 & 569 & 1764 & 5351 \\
\hline Slovakia & 0 & 31 & 400 & 1844 & 6147 & 26 & 55 & 563 & 1755 & 5356 \\
\hline Ireland & 0 & 29 & 336 & 1814 & 5929 & 25 & 45 & 500 & 1730 & 5176 \\
\hline Croatia & 0 & 24 & 308 & 1696 & 5624 & 24 & 38 & 438 & 1646 & 5169 \\
\hline Lithuania & 0 & 17 & 191 & 1431 & 5135 & 23 & 29 & 317 & 1356 & 4392 \\
\hline Slovenia & 0 & 11 & 149 & 1157 & 4471 & 18 & 42 & 260 & 1182 & 3952 \\
\hline Latvia & 0 & 11 & 141 & 1091 & 4318 & 17 & 42 & 249 & 1161 & 3862 \\
\hline Estonia & 0 & 8 & 99 & 809 & 3428 & 15 & 30 & 178 & 924 & 3171 \\
\hline Cyprus & 0 & 4 & 73 & 554 & 2620 & 12 & 29 & 123 & 676 & 2459 \\
\hline Luxembourg & 0 & 3 & 54 & 393 & 1998 & 12 & 20 & 87 & 532 & 1894 \\
\hline Malta & 0 & 3 & 40 & 286 & 1589 & 12 & 14 & 72 & 414 & 1478 \\
\hline Total & 7 & 388 & 1947 & 7552 & 19967 & 330 & 418 & 2464 & 6921 & 16930 \\
\hline
\end{tabular}

Source: Own calculations. 
Table 1 presented in the annex shows what the ability of member states to create small minimal blocking coalitions in the Council after Brexit will be, depending on the position of Germany with regard to the potential initiative, with the same assumptions that were adopted for the calculations in Table 3. The analysis of the data contained in it makes it possible to conclude that after the UK's withdrawal from the EU, Poland will not be a member of any the four- or five-member blocking coalitions built without the participation of Germany. Out of the 330 potential four-member minimal blocking coalitions, in 320 cases Germany is an indispensable member of such a coalition. At the same time, Berlin will have much greater freedom in choosing coalition partners for four-member minimal blocking coalitions. All EU states with populations under 10 million will also become potential coalition partners.

After Brexit, France will have a large capacity to build small, minimal blocking coalitions, even in the case of supporting a legislative initiative by the German government, provided that the position of the government in Paris is supported by another large EU state, especially Italy or Spain. At the same time, in the case of support for the legislative initiative by Germany, Poland's ability to form blocking coalitions consisting of six or seven states largely depends on the support of France, which would be an indispensable member of $83.3 \%$ and $74.1 \%$ of such coalitions which could to be set up by Poland, respectively.

The UK's withdrawal from the EU will also have an impact on the balance of power on the euro vs. non-euro axis. In the 28-state European Union, nine countries not belonging to the Eurozone (the United Kingdom, Poland, Romania, the Czech Republic, Sweden, Hungary, Denmark, Bulgaria, and Croatia) constitute approximately $33.34 \%$ of all EU residents. Therefore, they cannot set up a blocking coalition in the Council. However, not much would be needed to cross the threshold of $35 \%$ of the EU population: only one additional state with a population equal to or bigger than Austria or, for example, Ireland and Slovakia together. As a consequence, non-Eurozone member states could count on taking advantage of any discrepancies within the Eurogroup to protect their own interests. In addition, the political power of the United Kingdom in the Council was greater than what resulted from its formal voting weight in that institution.

After the UK's withdrawal from the EU, all the large EU states except Poland will belong to the European Monetary Union. The euro is currently the currency of 19 member states, and in the future one should expect an increase in this number. From this perspective, Brexit reduces Poland's chances to build a blocking coalition in the event of support for an initiative by Germany, France, Italy and Spain to almost zero. After Brexit, states not belonging to the Eurozone will constitute only slightly more than $23 \%$ of the EU population, and Poland will be the only large state in this group. Even if Poland's position is supported by Italy, the creation of a blocking coalition will be difficult due to the small number of potential coalition partners. In turn, the planned adoption of the euro currency by other member states ${ }^{31}$ will make it difficult to take advantage of the contradictions in interests among the Eurozone states.

31 Bulgaria, Romania and Croatia have made efforts to join the Eurozone. 


\section{THE IMPACT OF BREXIT ON POLAND'S ABILITY TO BUILD MINIMAL BLOCKING COALITIONS IN THE COUNCIL IN OPPOSITION TO THE GERMAN-FRENCH TANDEM}

Table 4 presents minimal blocking coalitions which Poland could establish together with Italy or Spain, with the following assumptions:

- qualified majority voting is applied;

- the legislative initiative enjoys the support of at least $55 \%$ of EU states;

- the legislative initiative is supported by Germany and France;

- the initiative is not supported by at most two large member states.

It shows how often individual member states can be an indispensable member of a minimal blocking coalition created around Poland and Italy, or built with the participation of Poland and Spain..$^{32}$ As indicated by the data in the table, the smallest blocking coalition possible to be built in cooperation with Italy must count at least six states, and in the case of cooperation with Spain, no fewer than eight states.

In the case of minimally blocking coalitions co-created by Poland and 5-7 Council members, the lack of support from Romania reduces the number of possible variants of such coalitions by 65\%-100\%, depending on the size of the coalition. Lack of support from the Netherlands would limit the available variants of a blocking coalition by $48 \%-100 \%$, depending on the size of the coalition. It should also be noted that the role of Lithuania, Latvia, and Estonia in building minimally blocking coalitions consisting of 6-8 states is small.

The demographic trends occurring in the European Union are likely to make it even more difficult for Poland to build blocking coalitions in opposition to Germany and France in the next few years.

Table 4. Participation of EU states in minimal blocking coalitions, possible to be created in the Council by Poland together with Italy or Spain, assuming that at least $55 \%$ of member states and three large EU states support the initiative of the European Commission

\begin{tabular}{|c|c|c|c|c|c|c|c|c|c|c|}
\hline & \multicolumn{4}{c|}{$\begin{array}{c}\text { Minimal blocking coalitions } \\
\text { involving Poland and Italy for EU-27 }\end{array}$} & \multicolumn{3}{c|}{$\begin{array}{c}\text { Minimal blocking coalitions } \\
\text { involving Poland and Spain for EU-27 }\end{array}$} \\
\hline & \multicolumn{3}{|c|}{ The number of coalition members } & \multicolumn{2}{|c|}{ The number of coalition members } \\
\hline & 6 & 7 & 8 & 9 & 10 & 8 & 9 & 10 & 11 & 12 \\
\hline Italy & 13 & 275 & 2055 & 5338 & 8812 & - & - & - & - & - \\
\hline Spain & - & - & - & - & - & 210 & 1606 & 5468 & 10847 & 14097 \\
\hline Poland & 13 & 275 & 2055 & 5338 & 8812 & 210 & 1606 & 5468 & 10847 & 14097 \\
\hline Romania & $100 \%$ & $90 \%$ & $65 \%$ & $45 \%$ & $32 \%$ & $100 \%$ & $90 \%$ & $71 \%$ & $59 \%$ & $48 \%$ \\
\hline
\end{tabular}

32 In Table 2 in the annex, the participation of individual states in minimal blocking coalitions is expressed in integral numbers. 


\begin{tabular}{|c|c|c|c|c|c|c|c|c|c|c|}
\hline \multirow{3}{*}{ Member state } & \multirow{2}{*}{\multicolumn{5}{|c|}{$\begin{array}{l}\text { Minimal blocking coalitions } \\
\text { involving Poland and Italy for EU-27 } \\
\text { The number of coalition members }\end{array}$}} & \multirow{2}{*}{\multicolumn{5}{|c|}{$\begin{array}{l}\text { Minimal blocking coalitions } \\
\text { involving Poland and Spain for EU-27 } \\
\text { The number of coalition members }\end{array}$}} \\
\hline & & & & & & & & & & \\
\hline & 6 & 7 & 8 & 9 & 10 & 8 & 9 & 10 & 11 & 12 \\
\hline Netherlands & $100 \%$ & $73 \%$ & $48 \%$ & $44 \%$ & $38 \%$ & $98 \%$ & $75 \%$ & $62 \%$ & $55 \%$ & $48 \%$ \\
\hline Belgium & $38 \%$ & $37 \%$ & $41 \%$ & $39 \%$ & $39 \%$ & $54 \%$ & $50 \%$ & $50 \%$ & $48 \%$ & $48 \%$ \\
\hline Greece & $38 \%$ & $31 \%$ & $40 \%$ & $39 \%$ & $39 \%$ & $51 \%$ & $45 \%$ & $48 \%$ & $48 \%$ & $49 \%$ \\
\hline Czech Republic & $38 \%$ & $28 \%$ & $40 \%$ & $39 \%$ & $39 \%$ & $47 \%$ & $47 \%$ & $48 \%$ & $48 \%$ & $48 \%$ \\
\hline Portugal & $31 \%$ & $33 \%$ & $39 \%$ & $39 \%$ & $40 \%$ & $47 \%$ & $45 \%$ & $47 \%$ & $48 \%$ & $48 \%$ \\
\hline Sweden & $31 \%$ & $31 \%$ & $38 \%$ & $39 \%$ & $39 \%$ & $45 \%$ & $43 \%$ & $47 \%$ & $47 \%$ & $48 \%$ \\
\hline Hungary & $23 \%$ & $33 \%$ & $39 \%$ & $38 \%$ & $39 \%$ & $42 \%$ & $43 \%$ & $46 \%$ & $48 \%$ & $48 \%$ \\
\hline Austria & $0 \%$ & $38 \%$ & $35 \%$ & $39 \%$ & $40 \%$ & $33 \%$ & $42 \%$ & $44 \%$ & $45 \%$ & $48 \%$ \\
\hline Bulgaria & $0 \%$ & $25 \%$ & $30 \%$ & $37 \%$ & $40 \%$ & $17 \%$ & $40 \%$ & $40 \%$ & $45 \%$ & $48 \%$ \\
\hline Denmark & $0 \%$ & $16 \%$ & $29 \%$ & $35 \%$ & $41 \%$ & $16 \%$ & $28 \%$ & $39 \%$ & $43 \%$ & $48 \%$ \\
\hline Finland & $0 \%$ & $15 \%$ & $28 \%$ & $36 \%$ & $41 \%$ & $14 \%$ & $28 \%$ & $38 \%$ & $43 \%$ & $48 \%$ \\
\hline Slovakia & $0 \%$ & $14 \%$ & $28 \%$ & $36 \%$ & $41 \%$ & $14 \%$ & $27 \%$ & $38 \%$ & $43 \%$ & $48 \%$ \\
\hline Ireland & $0 \%$ & $12 \%$ & $25 \%$ & $35 \%$ & $41 \%$ & $11 \%$ & $24 \%$ & $36 \%$ & $42 \%$ & $48 \%$ \\
\hline Croatia & $0 \%$ & $8 \%$ & $23 \%$ & $33 \%$ & $40 \%$ & $8 \%$ & $22 \%$ & $33 \%$ & $42 \%$ & $48 \%$ \\
\hline Lithuania & $0 \%$ & $4 \%$ & $15 \%$ & $29 \%$ & $40 \%$ & $2 \%$ & $16 \%$ & $28 \%$ & $39 \%$ & $48 \%$ \\
\hline Slovenia & $0 \%$ & $3 \%$ & $11 \%$ & $25 \%$ & $39 \%$ & $0 \%$ & $11 \%$ & $23 \%$ & $36 \%$ & $47 \%$ \\
\hline Latvia & $0 \%$ & $3 \%$ & $10 \%$ & $24 \%$ & $37 \%$ & $0 \%$ & $10 \%$ & $21 \%$ & $36 \%$ & $47 \%$ \\
\hline Estonia & $0 \%$ & $2 \%$ & $7 \%$ & $19 \%$ & $32 \%$ & $0 \%$ & $6 \%$ & $16 \%$ & $29 \%$ & $44 \%$ \\
\hline Cyprus & $0 \%$ & $1 \%$ & $4 \%$ & $13 \%$ & $26 \%$ & $0 \%$ & $4 \%$ & $11 \%$ & $23 \%$ & $37 \%$ \\
\hline Luxembourg & $0 \%$ & $1 \%$ & $3 \%$ & $9 \%$ & $21 \%$ & $0 \%$ & $3 \%$ & $8 \%$ & $18 \%$ & $31 \%$ \\
\hline Malta & $0 \%$ & $1 \%$ & $2 \%$ & $7 \%$ & $17 \%$ & $0 \%$ & $2 \%$ & $6 \%$ & $14 \%$ & $25 \%$ \\
\hline Total & 13 & 275 & 2055 & 5338 & 8812 & 210 & 1606 & 5468 & 10847 & 14097 \\
\hline
\end{tabular}

Source: Own calculations.

Table 5 presents a projection of the change in the population of the EU and selected states, as well as blocks of member states, according to a baseline scenario prepared by Eurostat, and also a sensitivity test assuming no migration..$^{33}$ As indicated by the data in the table, the analyses conducted by Eurostat assume that the inflow of immigrants will be concentrated mainly in a dozen or so member states, most of them characterized by a relatively high standard of living.

33 Vide: Eurostat, Comparison of the results from the AWG sensitivity tests on the 2015-based population projections, Luxembourg, 15 June 2017. 
Table 5. Projection of the population change for EU 27 and selected states and groups of member states in 2017-2020 (in millions of people)

\begin{tabular}{|c|c|c|c|c|c|c|c|c|}
\hline \multirow{2}{*}{ Member states } & \multicolumn{4}{|c|}{ Baseline projections } & \multicolumn{3}{|c|}{ Sensitivity test: no migration } \\
\cline { 2 - 8 } & 2020 & 2025 & $\mathbf{2 0 3 0}$ & 2035 & $\mathbf{2 0 2 0}$ & 2025 & 2030 & 2035 \\
\hline EU 27 & 2.0 & 4.4 & 5.9 & 6.7 & -4.1 & -6.8 & -11.3 & -17.1 \\
\hline Big 4* & 1.6 & 3.7 & 5.4 & 6.9 & -3.0 & -4.7 & -7.3 & -10.5 \\
\hline Germany & 1.3 & 1.9 & 2.2 & 2.1 & -2.2 & -3.5 & -5.2 & -7.2 \\
\hline France & 0.8 & 2.2 & 3.5 & 4.8 & 0.5 & 1.3 & 2.0 & 2.6 \\
\hline Italy & -0.5 & -0.7 & -0.9 & -1.0 & -1.2 & -2.4 & -3.7 & -5.2 \\
\hline Spain & 0.0 & 0.2 & 0.6 & 1.1 & -0.1 & -0.2 & -0.4 & -0.8 \\
\hline Poland & 0.0 & -0.3 & -0.8 & -1.4 & 0.0 & -0.3 & -0.7 & -1.3 \\
\hline Visegrad Group & 0.2 & -0.1 & -0.6 & -1.5 & -0.1 & -0.5 & -1.3 & -2.4 \\
\hline EU 14** & 2.5 & 6.3 & 9.6 & 12.4 & -3.9 & -5.6 & -8.6 & -12.6 \\
\hline EU 13** & -0.5 & -1.9 & -3.7 & -5.6 & -0.2 & -1.2 & -2.7 & -4.5 \\
\hline
\end{tabular}

* Big 4 - Germany, France, Italy and Spain.

** EU14 - the group of states that were granted EU membership in the $20^{\text {th }}$ century, with the exception of the United Kingdom.

*** UE13 - the group of states that were granted EU membership in 2004-2013.

Source: Own calculations based on Eurostat, Population on $1^{\text {st }}$ January by age, sex and type of projection, at <http://appsso.eurostat.ec.europa.eu/nui/show.do?dataset=proj_15npms\&lang=en>.

According to Eurostat estimates, by 2035 the population of Poland will have decreased by 1.4 million, and that of the Visegrad Group by 1.5 million. At the same time, the populations of France and Germany will have increased by 4.8 million and 2.1 million, respectively. By 2035, the population in the so-called "old" member states, which became EU members in the $20^{\text {th }}$ century, is to increase by 12.4 million, while in the "new" EU countries it is to decrease by 5.6 million. Countries such as Germany, Italy, Austria, Denmark, Belgium, the Netherlands, Sweden, Luxembourg, Malta and Cyprus will benefit from a relatively high, specific "migration bonus", an increase in population as a consequence of migratory movements. It should be emphasized that in the absence of cross-border migratory movements of people, the population of the EU14 (the fourteen "old" EU countries excluding the United Kingdom) in 2035 would not only fail to increase, but it would decrease by 12.6 million people. At the same time, in the case of a higher level of immigration to the EU than that assumed for the base scenario of the projection of the population, the predominance of the EU14 population over the groups of countries that made accession in the years 2004-2013 would increase. 


\section{CONCLUSIONS}

The presented results indicate that Brexit may have a significant impact on Poland's ability to build minimal blocking coalitions in the Council, as well as on the position of individual actors in the decision-making process in the EU.

The UK's withdrawal from the EU will strengthen the positions of the other five member states with the largest populations in the Council, in particular Germany and France. The position of the five most populous member states will determine the scope of any possible compromises in the Council to an even greater extent. In this group, Poland will benefit the least from the change that will take place in the vote-weighing system as a result of Brexit.

The modification of the vote weighing system in the Council, which will take place as a result of Brexit, may pose a threat to the Community method, as it will limit the ability of the European Commission to balance the interests of large and smaller member states in the law-making process, as well as reduce its freedom to propose solutions in the legislative initiatives prepared by it. On the other hand, it may also tempt the European Commission to support the interests of selected, major EU states, in order to speed up the decision-making process, which will significantly hamper the formation of a blocking coalition in the Council.

The adoption of a decision in the Council against the position of the GermanFrench tandem, although theoretically possible, will be highly unlikely in practice. If Berlin and Paris coordinate their positions, they will become an indispensable member of $99.99 \%$ of the theoretically possible winning coalitions in the Council.

Building a blocking coalition by Poland, without the support of even one large EU state, will be highly unlikely and practically always doomed to failure due to the lack of a sufficient number of coalition members with correspondingly large populations. Building blocking coalitions against the support of any initiative by Germany and France will be especially difficult for Warsaw. In such cases, a blocking coalition formed by Poland together with Italy or Spain must number at least 7-8 states. A question arises as to the extent to which the convergence of the interests of Poland, Italy or Spain can be expected. The support of Poland's position by Romania and/or the Netherlands will also have a significant impact on the ability of the government in Warsaw to form blocking coalitions.

The loss of the United Kingdom as a potential coalition partner will weaken Poland's position in negotiations on the EU forum in the cases of those issues in which it is difficult to count on the support of another large member state. For example, the United Kingdom has strongly opposed attempts to introduce regulations or protectionist practices in the EU internal market. London has differed on many issues from the positions presented by Rome and Madrid, and the United Kingdom is the only big country, apart from Poland, not belonging to the Eurozone. In addition, there is a significant divergence of interests among Poland and Italy and Spain in issues such as the multiannual financial framework, cohesion policy, common immigration and asylum 
policy, and Eurozone reform. It is also difficult to expect strong support on the part of these countries for Poland's position with respect to EU climate policy. The government of Prime Minister Giusseppe Conte also presents a different perspective on the issue of cooperation with Russia. In addition, governments in Italy have historically had little stability, which may make it difficult to coordinate positions.

After Brexit, the Eurozone countries will have, in the context of decision-making by qualified majority, a clear majority in the Council ( 19 states constituting over $77 \%$ of the EU population), which creates the risk that de facto decisions on economic and financial matters will be made in the Eurogroup, and the Economic and Financial Affairs Council (ECOFIN) will only be used for official approval. The adoption of the single euro currency by other member states will make it difficult to build blocking coalitions in the Council by taking advantage of the contradictions within the Eurozone.

The expected demographic changes in the European Union, from the perspective of their impact on the voting power of states in the Council, are unfavourable to Poland. First of all, it is pointed out that it will become increasingly difficult for Warsaw to build small blocking coalitions against the support of any initiative by Germany and France. The population of both Germany and France is expected to grow significantly, while in Poland and in the entire Visegrad Group it is expected to decrease, mainly as a result of a decline in Poland. It should be remembered that the formation of a blocking coalition by Poland, in opposition to the German-French tandem, requires in practice winning at least one large member of the Council. The population of Italy is not going to change significantly, and the increase in the population in Spain will be counterbalanced by the decline in the population of Poland, which will not facilitate the creation of blocking coalitions. A systematic increase in the predominance of EU14 states over EU13 states in terms of population is also predicted, and it is in the latter group that it may be easier for Poland to find coalition partners with similar interests due to historical, socio-economic, cultural and geopolitical conditions. As a consequence, demographic trends may lead to the strengthening of the voting power of especially old member states, primarily France and Germany.

\section{BIBLIOGRAPHY}

Belke A., Styczynska B., The Allocation of Power in the Enlarged ECB Governing Council: An Assessment of the ECB Rotation Model, Brussels 2004.

Bilbao J.M. et al., "Voting Power in the European Union Enlargement", European Journal of Operational Research, vol. 143, no. 1 (2002), https://doi.org/10.1016/S0377-2217(01)00334-4.

Brandsma G.J., "Co-Decision after Lisbon: The politics of Informal Trilogues in European Union Lawmaking", European Union Politics, vol. 16, no. 2 (2015), https://doi. org/10.1177/1465116515584497.

Bressanelli E., Koop Ch., Reh Ch., "The Impact of Informalisation: Early Agreements and Voting Cohesion in the European Parliament", European Union Politics, vol. 17, no. 1 (2016), https://doi.org/10.1177/1465116515608704. 
Clark J., Jones A., “'Telling Stories about Politics': Europeanization and the EU's Council Working Groups”, Journal of Common Market Studies, vol. 49, no. 2 (2011), https://doi. org/10.1111/j.1468-5965.2010.02143.x.

Consolidated version of the Treaty on European Union, Official Journal of the European Union, C 202, 7 June 2016.

Deegan J., Packel E.W., "A New Index of Power for Simple n-Person Games”, International Journal of Game Theory, vol. 7, no. 2 (1979), p. 114, at https://doi.org/10.1007/BF01753239.

Eurostat, Comparison of the results from the AWG sensitivity tests on the 2015-based population projections, Luxembourg, 15 June 2017.

Eurostat, Population on $1^{\text {st }}$ January by age, sex and type of projection, at <http://appsso.eurostat. ec.europa.eu/nui/show.do ?dataset $=$ proj_15npms\&lang $=$ en $>$.

Eurostat, Usually resident population on 1 January (last update on October 2, 2017), at <http:// appsso.eurostat.ec.europa.eu/nui/show.do?dataset=demo_urespop\&lang=en >.

Farrell H., Héritier A., The Invisible Transformation of Codecision: Problems of Democratic Legitimacy, SIEPS Report No. 7, Stockholm 2003, at <http://www.sieps.se/en/publications/2003/the-invisible-transformation-of-codecision-problems-of-democratic-legitimacy-20037/Sieps_2003_7.pdf>.

Felsenthal D.S., Machover M., The Measurement of Voting Power. Theory and Practice, Problems and Paradoxes, Cheltenham 1998.

Hagemann S., De Clerck-Sachsse J., "Old Rules, New Game. Decision-Making in the Council of Ministers after the 2004 Enlargement”, Centre for European Policy Studies Special Report (2007), at <http://aei.pitt.edu/11754/1/1470.pdf>.

Harsanyi J.C., Selten R., A General Theory of Equilibrium Selection in Games, Cambridge 1988. Hayes-Renshaw F., Aken W. van, Wallace H., "When and Why the EU Council of Ministers Votes Explicitly", Journal of Common Market Studies, vol. 44, no. 1 (2006), https://doi. org/10.1111/j.1468-5965.2006.00618.x.

Häge F.M., "Coalition Building and Consensus in the Council of the European Union”, British Journal of Political Science, vol. 43, no. 3 (2013), https://doi.org/10.1017/ S0007123412000439.

Heisenberg D., "The Institution of 'Consensus' in The European Union: Formal Versus Informal Decision-Making in The Council”, European Journal of Political Research, vol. 44, no. 1 (2005), https://doi.org/10.1111/j.1475-6765.2005.00219.x.

Kleinowski M., Sita państw w Unii Europejskiej. Pozaformalne wyznaczniki sity państw w Radzie UE i Radzie Europejskiej, Toruń 2014.

Kleinowski M., "Konsensualne negocjacje czy głosowanie - kontestowanie aktów prawnych w Radzie UE”, Studia Europejskie, no. 4 (2012), at <https://www.ce.uw.edu.pl/pliki/pw/ marcin_kleinowski.pdf $>$.

Lewis J., "The Janus Face of Brussels. Socialization and Everyday Decision Making in the European Union", in J.T. Checkel (ed.), International Institutions and Socialization in Europe, Cambridge 2007.

Mattila M., "Voting and Coalitions in the Council after the Enlargement", in D. Naurin, H. Wallace (eds.), Unveiling the Council of the European Union. Games Governments Play in Brussels, Basingstoke 2008. 
Mattila M., "Contested Decisions: Empirical Analysis of Voting in the European Union Council of Ministers”, European Journal of Political Research, vol. 43, no. 1 (2004), https://doi. org/10.1111/j.1475-6765.2004.00144.x.

Moberg A., Is the Double Majority Really Double? The Second Round in the Debate of the Voting Rules in the EU Constitutional Treaty, Real Instituto Elcano Working Paper, no. 290, Ma$\operatorname{drid} 2007$.

Neumann J. von, Morgenstern O., Theory of Games and Economic Behavior, Princeton 1944.

Novak S., Qualified Majority Voting from the Single European Act to Present Day: An Unexpected Permanence, Studies and Research, 88, at <http://institutdelors.eu/wp-content/uploads/2018/01/etud88_en-qualifiedmajority-voting-novak.pdf $>$.

Owen G., Game Theory, 3rd ed., London 1995.

Regulation (EU) No 1260/2013 of the European Parliament and of the Council of 20 November 2013 on European demographic statistics, Official Journal of the European Union, L 330, 10 December 2013.

Roederer-Rynning Ch., Greenwood J., “The Culture of Trilogues”, Journal of European Public Policy, vol. 22, no. 8 (2015), https://doi.org/10.1080/13501763.2014.992934.

Sozański T., "The Conception of Blocking Power as a Key to the Understanding of the History of Designing Voting Systems for the EU Council”, Decyzje, no. 22 (2014), http://dx.doi. org/10.7206/DEC.1733-0092.32.

Thomson R., Resolving Controversy in the European Union. Legislative Decision-Making before and after Enlargement, Cambridge 2011.

Warntjen A., "Do Votes Matter? Voting Weights and the Success Probability of Member State Requests in the Council of the European Union", Journal of European Integration, vol. 39, no. 6 (2017), https://doi.org/10.1080/07036337.2017.1332057.

\section{ANNEX}

Table 1. Small, minimal blocking coalitions possible to be set up in the Council, assuming that at least $55 \%$ of member states and three large EU states support the initiative of the European Commission

\begin{tabular}{|c|c|c|c|c|c|c|c|c|c|c|}
\hline \multirow{3}{*}{ Member state } & \multirow{2}{*}{\multicolumn{5}{|c|}{$\begin{array}{c}\text { Minimal blocking coalitions } \\
\text { involving Germany for EU-27 } \\
\text { The number of coalition members }\end{array}$}} & \multirow{2}{*}{\multicolumn{5}{|c|}{$\begin{array}{l}\text { Minimal blocking coalitions not } \\
\text { involving Germany for EU-27 } \\
\text { The number of coalition members }\end{array}$}} \\
\hline & & & & & & & & & & \\
\hline & 4 & 5 & 6 & 7 & 8 & 4 & 5 & 6 & 7 & 8 \\
\hline Germany & 320 & 275 & 1260 & 2519 & 4504 & - & - & - & - & - \\
\hline France & 189 & 21 & 7 & 3 & 0 & 10 & 143 & 1052 & 3143 & 7046 \\
\hline Italy & 117 & 83 & 89 & 47 & 23 & 10 & 135 & 787 & 2276 & 6249 \\
\hline Spain & 13 & 117 & 656 & 939 & 936 & 0 & 8 & 491 & 2321 & 6502 \\
\hline Poland & 1 & 54 & 508 & 1435 & 2262 & 0 & 0 & 78 & 1064 & 5052 \\
\hline Romania & 51 & 61 & 220 & 275 & 1368 & 8 & 29 & 470 & 1777 & 4445 \\
\hline Netherlands & 49 & 55 & 203 & 418 & 1384 & 3 & 80 & 377 & 1567 & 4183 \\
\hline
\end{tabular}




\begin{tabular}{|c|c|c|c|c|c|c|c|c|c|c|}
\hline \multirow{3}{*}{ Member state } & \multirow{2}{*}{\multicolumn{5}{|c|}{$\begin{array}{c}\text { Minimal blocking coalitions } \\
\text { involving Germany for EU-27 } \\
\text { The number of coalition members }\end{array}$}} & \multirow{2}{*}{\multicolumn{5}{|c|}{$\begin{array}{l}\text { Minimal blocking coalitions not } \\
\text { involving Germany for EU-27 } \\
\text { The number of coalition members }\end{array}$}} \\
\hline & & & & & & & & & & \\
\hline & 4 & 5 & 6 & 7 & 8 & 4 & 5 & 6 & 7 & 8 \\
\hline Belgium & 41 & 45 & 304 & 582 & 1255 & 2 & 21 & 375 & 1323 & 4131 \\
\hline Greece & 40 & 41 & 278 & 638 & 1371 & 2 & 19 & 339 & 1346 & 4258 \\
\hline Czech Republic & 38 & 47 & 275 & 626 & 1318 & 1 & 35 & 329 & 1285 & 4225 \\
\hline Portugal & 38 & 42 & 307 & 606 & 1384 & 1 & 34 & 309 & 1348 & 4182 \\
\hline Sweden & 38 & 40 & 295 & 628 & 1363 & 1 & 32 & 304 & 1359 & 4132 \\
\hline Hungary & 37 & 49 & 293 & 647 & 1378 & 1 & 31 & 282 & 1354 & 4223 \\
\hline Austria & 36 & 41 & 248 & 794 & 1409 & 1 & 28 & 221 & 1305 & 4068 \\
\hline Bulgaria & 32 & 56 & 258 & 670 & 1343 & 0 & 27 & 241 & 1227 & 3895 \\
\hline Denmark & 28 & 38 & 314 & 728 & 1402 & 0 & 14 & 258 & 1057 & 3889 \\
\hline Finland & 28 & 31 & 328 & 742 & 1412 & 0 & 14 & 241 & 1022 & 3939 \\
\hline Slovakia & 26 & 42 & 322 & 738 & 1414 & 0 & 13 & 241 & 1017 & 3942 \\
\hline Ireland & 25 & 34 & 291 & 749 & 1412 & 0 & 11 & 209 & 981 & 3764 \\
\hline Croatia & 24 & 27 & 268 & 756 & 1466 & 0 & 11 & 170 & 890 & 3703 \\
\hline Lithuania & 23 & 21 & 188 & 634 & 1445 & 0 & 8 & 129 & 722 & 2947 \\
\hline Slovenia & 18 & 36 & 163 & 570 & 1366 & 0 & 6 & 97 & 612 & 2586 \\
\hline Latvia & 17 & 37 & 159 & 558 & 1335 & 0 & 5 & 90 & 603 & 2527 \\
\hline Estonia & 15 & 25 & 124 & 471 & 1162 & 0 & 5 & 54 & 453 & 2009 \\
\hline Cyprus & 12 & 26 & 86 & 354 & 961 & 0 & 3 & 37 & 322 & 1498 \\
\hline Luxembourg & 12 & 18 & 63 & 284 & 756 & 0 & 2 & 24 & 248 & 1138 \\
\hline Malta & 12 & 13 & 53 & 222 & 603 & 0 & 1 & 19 & 192 & 875 \\
\hline Total & 320 & 275 & 1260 & 2519 & 4504 & 10 & 143 & 1204 & 4402 & 12426 \\
\hline
\end{tabular}

Source: Own calculations.

Table 2. Small, minimal blocking coalitions possible to be created in the Council by Poland together with Italy or Spain, assuming that at least 55\% of member states and three large EU states support the initiative of the European Commission.

\begin{tabular}{|c|c|c|c|c|c|c|c|c|c|c|}
\hline \multirow{3}{*}{ Member state } & \multirow{2}{*}{\multicolumn{5}{|c|}{$\begin{array}{l}\text { Minimal blocking coalitions } \\
\text { involving Poland and Italy for EU-27 }\end{array}$}} & \multirow{2}{*}{\multicolumn{5}{|c|}{$\begin{array}{l}\text { Minimal blocking coalitions } \\
\text { involving Poland and Spain for EU-27 } \\
\text { The number of coalition members }\end{array}$}} \\
\hline & & & & & The number of coalition members & & & & & \\
\hline & 6 & 7 & 8 & 9 & 10 & 8 & 9 & 10 & 11 & 12 \\
\hline Italy & 13 & 275 & 2055 & 5338 & 8812 & - & - & - & - & - \\
\hline Spain & - & - & - & - & - & 210 & 1606 & 5468 & 10847 & 14097 \\
\hline Poland & 13 & 275 & 2055 & 5338 & 8812 & 210 & 1606 & 5468 & 10847 & 14097 \\
\hline
\end{tabular}




\begin{tabular}{|c|c|c|c|c|c|c|c|c|c|c|}
\hline \multirow{3}{*}{ Member state } & \multirow{2}{*}{\multicolumn{5}{|c|}{$\begin{array}{l}\text { Minimal blocking coalitions } \\
\text { involving Poland and Italy for EU-27 } \\
\text { The number of coalition members }\end{array}$}} & \multirow{2}{*}{\multicolumn{5}{|c|}{$\begin{array}{l}\text { Minimal blocking coalitions } \\
\text { involving Poland and Spain for EU-27 } \\
\text { The number of coalition members }\end{array}$}} \\
\hline & & & & & & & & & & \\
\hline & 6 & 7 & 8 & 9 & 10 & 8 & 9 & 10 & 11 & 12 \\
\hline Romania & 13 & 247 & 1330 & 2390 & 2822 & 210 & 1443 & 3895 & 6355 & 6757 \\
\hline Netherlands & 13 & 201 & 980 & 2355 & 3382 & 206 & 1210 & 3373 & 5996 & 6768 \\
\hline Belgium & 5 & 101 & 836 & 2102 & 3401 & 114 & 803 & 2745 & 5234 & 6764 \\
\hline Greece & 5 & 85 & 825 & 2108 & 3449 & 107 & 729 & 2613 & 5190 & 6844 \\
\hline Czech Republic & 5 & 78 & 813 & 2071 & 3420 & 99 & 749 & 2607 & 5167 & 6790 \\
\hline Portugal & 4 & 90 & 799 & 2064 & 3490 & 99 & 717 & 2564 & 5183 & 6774 \\
\hline Sweden & 4 & 85 & 779 & 2087 & 3444 & 95 & 688 & 2596 & 5140 & 6727 \\
\hline Hungary & 3 & 91 & 799 & 2041 & 3459 & 88 & 698 & 2533 & 5157 & 6740 \\
\hline Austria & 0 & 104 & 721 & 2073 & 3529 & 70 & 671 & 2418 & 4926 & 6780 \\
\hline Bulgaria & 0 & 70 & 626 & 1968 & 3511 & 36 & 635 & 2200 & 4841 & 6807 \\
\hline Denmark & 0 & 44 & 598 & 1877 & 3587 & 33 & 444 & 2131 & 4690 & 6759 \\
\hline Finland & 0 & 40 & 578 & 1904 & 3571 & 29 & 449 & 2099 & 4658 & 6770 \\
\hline Slovakia & 0 & 38 & 582 & 1901 & 3582 & 29 & 441 & 2067 & 4694 & 6734 \\
\hline Ireland & 0 & 32 & 505 & 1851 & 3612 & 24 & 383 & 1976 & 4595 & 6787 \\
\hline Croatia & 0 & 23 & 471 & 1783 & 3567 & 17 & 356 & 1784 & 4592 & 6713 \\
\hline Lithuania & 0 & 12 & 317 & 1559 & 3561 & 4 & 249 & 1544 & 4231 & 6756 \\
\hline Slovenia & 0 & 9 & 219 & 1347 & 3407 & 0 & 172 & 1244 & 3954 & 6631 \\
\hline Latvia & 0 & 9 & 205 & 1306 & 3292 & 0 & 164 & 1175 & 3878 & 6671 \\
\hline Estonia & 0 & 6 & 140 & 988 & 2838 & 0 & 100 & 868 & 3166 & 6158 \\
\hline Cyprus & 0 & 4 & 91 & 709 & 2295 & 0 & 64 & 582 & 2510 & 5270 \\
\hline Luxembourg & 0 & 3 & 66 & 504 & 1813 & 0 & 45 & 418 & 1930 & 4395 \\
\hline Malta & 0 & 3 & 50 & 378 & 1464 & 0 & 32 & 312 & 1536 & 3575 \\
\hline Total & 13 & 275 & 2055 & 5338 & 8812 & 210 & 1606 & 5468 & 10847 & 14097 \\
\hline
\end{tabular}

Source: Own calculations.

Marcin KLEINOWSKI - a Doctor of Political Science at Nicolaus Copernicus University in Torun, Poland. His main research interests are focused on the process of European integration with particular emphasis on decision-making in the European Union. 